\title{
An Osmotic Barrier for Inorganic Phosphate in Chick Embryo Cells and its Stability during the Latent and Re- lease Periods of Infection by Vesicular Stomatitis Virus
}

\author{
BY P. D. COOPER* \\ Division of Biology, California Institute of Technology, Pasadena, \\ California, U.S.A.
}

\begin{abstract}
SUMMARY: An osmotic barrier for phosphate very near the visible surface of the chick-embryo cell appears to regulate the reciprocal exchange of inorganic orthophosphate between the medium and a component of the acid-soluble inorganic phosphate of cells kept in monolayer culture. Some non-reciprocal transfer of inorganic phosphate occurs, which may or may not be due to cell damage, and the apparent phosphate-impermeable volume decreases by half after $3 \mathrm{hr}$. contact with phosphate at $0^{\circ}$. At $2^{\circ}$ the exchange is at least $97 \%$ inhibited. The phosphateimpermeable volume after cell rupture is less than $10 \%$ of the intact-cell value, when internal phosphate is released in a form shown by mild separation to be mostly inorganic orthophosphate. Cells lose internal phosphate more slowly in absence of external phosphate, and the addition of external phosphate increases the loss rate to a maximum at physiological concentrations and higher.

Such a barrier provides information on the nature of the cell surface, and shows that adsorption, penetration and release of vesicular stomatitis virus occurs without any detectable damage to the surface controlling the phosphate-exchange rate.
\end{abstract}

Workers generally agree (e.g. Kamen \& Spiegelman, 1948; Sacks, 1948; Mitchell \& Moyle, 1953) that concentration of inorganic phosphate into cells does not depend much on simple diffusion alone, but also involves enzymic mechanisms which are possibly phosphorylative. The major uncertainties reside in whether $(a)$ these are exclusively surface mechanisms, so that internal orthophosphate is free within an acid-labile osmotic barrier, or whether (b) the phosphate diffuses freely, to be immobilized enzymically by some intracellular acid-labile matrix. Sacks (1948) believed the evidence indicated possibility ( $a$ ) for animal cells, but he considered only the alternative of simple physical diffusion (i.e. with no enzymic mechanism) rather than (b). Similar possibilities have been discussed by Mitchell (1953) for Micrococcus pyogenes (Staphylococcus aureus) under the titles of $(a)$ exchange-diffusion and, $(b)$ exchange adsorption, although simple physical adsorption does not apply in the cases discussed below. Exchange diffusion was preferred, as the cells appeared completely impermeable to phosphate in the cold, but freely permeable when the osmotic barrier was destroyed by acid or $5 \%(v / v)$ butanol in water. Some substances inhibited exchange at concentrations too low for stoichiometric displacement of adsorbed phosphate, but this does not disprove intracellular fixation, as it only indicates that a catalytic rather than a physical adsorption fixation mechanism is operating. More recent evidence is available to indicate

\footnotetext{
* Present address: Virus Culture Laboratory, M.R.C. Laboratories, Carshalton, Surrey.
} 
that phosphate and other ions exist in the free state within an osmotic barrier in bacteria (Mitchell \& Moyle, 1956).

Greenberg (1952) felt at that time that evidence for the mechanism of phosphate uptake by animal cells was inconclusive. The data presented below seem more definitely in favour of the existence of an osmotic barrier for orthophosphate close to the chick-embryo cell wall, through which by definition phosphate ions do not pass freely but require a transport mechanism that turns out to be very dependent on temperature. Such a barrier can provide information on superficial aspects of the viral growth cycle such as adsorption, penetration and release of the virus. Evidence is presented here that these processes during infection by vesicular stomatitis (VS) virus do not detectably affect the rate of phosphate exchange, suggesting that the phosphate barrier remains substantially intact until at least $50 \%$ of the virus yield has been released.

\section{METHODS}

Virus stocks, virus and ${ }^{32} \mathrm{P}$ assays, media, preparation of chick embryo cells and monolayers, and the one-step growth curves used in the 'loss' experiments were as described by Cooper $(1957 a, b)$.

Measurement of phosphate-impermeable volume (Table 1). Ten $20 \mathrm{hr}$. cell monolayers were washed with warm phosphate buffer saline (PBS) and the cells removed by $10 \mathrm{~min}$. incubation with $\mathbf{0 . 2 5} \%$ trypsin in Earle's saline, washed once with cold PBS, chilled thoroughly in ice-water and centrifuged at $500 \mathrm{~g}$ for $2 \mathrm{~min}$. in a urine-protein centrifuge tube, accurately calibrated to $0.4 \mathrm{ml}$. by $0.01 \mathrm{ml}$. intervals and to $1 \mathrm{ml}$. by $0.1 \mathrm{ml}$. intervals. The pellet volume was $c .0 \cdot 4 \mathrm{ml}$. The supernatant fluid was sucked off, the remaining volume noted, then $0.5 \mathrm{ml}$. of cold PBS containing about $0.1 \mu \mathrm{c}{ }^{32} \mathrm{P}$ (accurately known) and $150 \mu \mathrm{g}$. $\mathrm{P}$ was added, and the cells thoroughly resuspended by gentle pipetting. A $0.1 \mathrm{ml}$. sample ('1st sample') was diluted into $1.9 \mathrm{ml}$. PBS for total ${ }^{32} \mathrm{P}$ and haemocytometer cell counts; the suspension contained single cells free of debris with a few clumps of 2-3 cells. This sample gives the total number of cells in the preparation, and comparison of its ${ }^{32} \mathrm{P}$ content with that known to be added gave the efficiency of mixing (complete within experimental error). Since rate of $P$ exchange did not increase above $0.8 \mathrm{~mm}$ (Fig. 2), the use of the higher phosphate concentration of PBS (10 mM) rather than Earle's saline minimized loss of ${ }^{32} P$ from the supernatant fluid by reciprocal exchange. Any loss was then due to diffusion into the cell; keeping the cells at $0^{\circ}$ (see below) decreased any exchange still further. After sampling ('1st sample'), the tube was centrifuged for $2 \mathrm{~min}$. at $500 \mathrm{~g}$ in an ice-filled cup. A $0 \cdot 1 \mathrm{ml}$. sample (' 2 nd sample') was removed from the supernatant fluid for ${ }^{32} \mathrm{P}$ assay and the pellet volume noted. The cells were resuspended and the whole contents frozen in dry-ice +ethanol mixture and thawed (one cycle), when the cell debris was centrifuged at $1000 \mathrm{~g}$ for $5 \mathrm{~min}$. and the supernatant was assayed for ${ }^{32} \mathrm{P}$ ('3rd sample'). Finally the sediment was resuspended and a sample was taken for intact cell count (" 4 th sample'). The experiment was performed with a short ( $3 \mathrm{~min}$.) and a long (180 min.) interval between addition of ${ }^{32} \mathrm{P}$ and centrifuging. 


\section{RESULTS}

\section{Temperature dependence of phosphate exchange}

A 32P 'loss' experiment (Cooper, 1957b) was performed, one set of washed radioactive monolayers overlaid with non-radioactive fluid medium being held at $37^{\circ}$ in a $\mathrm{CO}_{2}$ incubator, and another identical set at $3^{\circ}$ in a vacuum desiccator filled with a $5 \%(\mathrm{v} / \mathrm{v}) \mathrm{CO}_{2}$ in air mixture. The rate of ${ }^{32} \mathrm{P}$ release in the cold plates during the first $4 \mathrm{hr}$. was about $3 \%$ of the rate at $37^{\circ}$, indicating that simple diffusion did not play much part in the release and that phosphate exchange at $0^{\circ}$ was likely to be negligible. This was to be expected from the suspected enzymic nature of the exchange, and did not exclude 'exchange adsorption', but its demonstration was relevant for the experiment to be described next.

\section{Phosphate-impermeable volume}

Determination of this volume depends upon the changes in extracellular ${ }^{32} \mathrm{P}$ concentration observed when a known amount of ${ }^{32} \mathrm{P}$ in a known volume is added to a cold thick cell suspension, using the procedure described in Methods. The results are given in Table 1, and indicate that under these con-

Table 1. 'Phosphate-impermeable volumes' of chick embryo cells, measured after 3 and 180 min. contact with external ${ }^{32} \mathrm{PO}_{4}$.

Column 3 is calculated on the assumption that all ${ }^{32} \mathrm{P}$ is extracellular, althouth this is probably not so after $180 \mathrm{~min}$. contact. No attempt was made to measure the minimum pellet volume (i.e. hard-packed cells) for fear of damaging the cells .

\begin{tabular}{|c|c|c|c|c|c|c|c|c|}
\hline i & $\begin{array}{l}\text { Total }{ }^{32} \mathbf{P} \\
\text { content of } \\
\text { prepn. } \\
\text { (cts./min.) } \\
\text { (1) }\end{array}$ & $\begin{array}{l}{ }^{32} \mathrm{P} \text { content } \\
\text { of supernatant } \\
\text { (cts./min./ml.) } \\
\text { (2) }\end{array}$ & $\begin{array}{c}\text { Therefore } \\
\text { vol. } \\
\text { extra- } \\
\text { cellular } \\
\text { fluid } \\
1 \div 2 \\
\text { (ml.) } \\
\text { (3) }\end{array}$ & $\begin{array}{c}\text { Total } \\
\text { vol. } \\
\text { of } \\
\text { prepn. } \\
\text { (ml.) } \\
(4)\end{array}$ & $\begin{array}{l}\text { Therefore } \\
\text { P-im- } \\
\text { permeable } \\
\text { vol. } \\
\text { (4)- }(3) \\
\text { (ml.) } \\
\text { (5) }\end{array}$ & $\begin{array}{l}\text { Vol. } \\
\text { pellet } \\
(\mathrm{ml} .) \\
(6)\end{array}$ & $\begin{array}{l}\text { Therefore } \\
\text { inter- } \\
\text { cellular } \\
\text { space } \\
\left(\frac{(6)-(5)}{(6)}\right) \\
(7)\end{array}$ & $\begin{array}{c}\text { Total No, } \\
\text { intact } \\
\text { cells } \\
\text { (visible } \\
\text { count) } \\
\times 10^{7} \\
(8)\end{array}$ \\
\hline $\begin{array}{l}3 \text { min. contact } \\
\text { After Ist sample and } \\
\text { centrifuging }\end{array}$ & $3.50 \times 10^{4}$ & $4.80 \times 10^{4}$ & 0.73 & 0.92 & $0 \cdot 19$ & $0 \cdot 39$ & 0.51 & $18 \cdot 4$ \\
\hline $\begin{array}{l}\text { centrifuging } \\
\text { After } 2 \text { nd sample, } \\
\text { freeze thaw and } \\
\text { centrifuging }\end{array}$ & $3.03 \times 10^{4}$ & $3.78 \times 10^{4}$ & 0.80 & 0.82 & c. 0.02 & $0 \cdot 38$ & c. 0.95 & $1 \cdot 2$ \\
\hline $\begin{array}{l}180 \text { min. contact } \\
\text { After 1st sample and } \\
\text { centrifuging }\end{array}$ & $8.04 \times 10^{5}$ & $10.7 \times 10^{5}$ & 0.75 & 0.90 & 0.15 & $0 \cdot 39$ & $0 \cdot 62$ & $28 \cdot 4$ \\
\hline $\begin{array}{l}\text { After } 2 \text { nd sample, } \\
\text { freeze thaw and } \\
\text { centrifuging }\end{array}$ & $6.97 \times 10^{5}$ & $8.90 \times 10^{5}$ & 0.78 & $0 \cdot 80$ & c. 0.02 & 0.39 & c. 0.95 & $3 \cdot 5$ \\
\hline
\end{tabular}

ditions the phosphate-impermeable volume of $18 \cdot 4 \times 10^{7}$ cells was $0 \cdot 19 \mathrm{ml}$. ( 3 min. contact), so that the average phosphate-impermeable volume/cell was $1030 \mu^{3}$ (radius $=6 \cdot 26 \mu$ ). These are very similar values to those of Dulbecco \& Vogt (1954) for the visible dimensions of these cells (mean $=1180 \mu^{3}$, radius $=6.55 \mu)$. The phosphate-impermeable volume is likely to be somewhat less than the total volume of the cells (compare Micrococcus pyogenes (Staphylococcs aureus), Mitchell, 1953), but it is not legitimate to calculate the depth of the barrier below the visible surface from these figures. The intercellular space is within the expected range for non-uniform non-deformable spherical objects. 
After $180 \mathrm{~min}$. contact at $0^{\circ}$ the apparent phosphate-impermeable volume had decreased to $528 \mu .3 /$ cell, suggesting that phosphate was able to pass the osmotic barrier slowly under these circumstances, a finding supported by the small but significant leakage of ${ }^{32} \mathrm{P}$ at $3^{\circ}$ and the slow release of ${ }^{32} \mathrm{P}$ in absence of external phosphate at $37^{\circ}$; thus transfer of phosphate may not be strictly by reciprocal exchange, even in the non-growing cell.

Rupture of the cells, by one cycle of freezing and thawing, immediately (within the centrifuging time of 2-3 min.) diminished the phosphate-impermeable volume to $<10 \%$ of the intact volume; the pellet volume of the debris was the same as that of the cells, but the supernatant fluid had become viscous and opalescent.

\section{Phosphate-retaining mechanism}

One would think it necessary for cell function that a phosphate-excluding barrier should also be able to retain phosphate already in the cell. That this is so is shown by the relatively slow leakage at $37^{\circ}$ in the absence of external phosphate (Figs. 1, 2) and the almost complete retention at $5^{\circ}$, while rupture of the cell by freezing-thawing (Table 4, Cooper, 1957 b) or by shearing forces

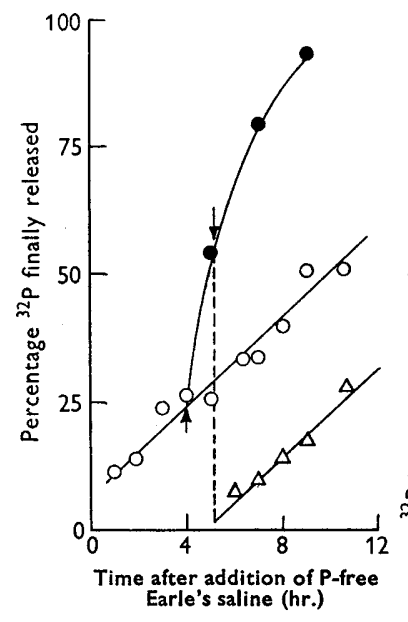

Fig. 1

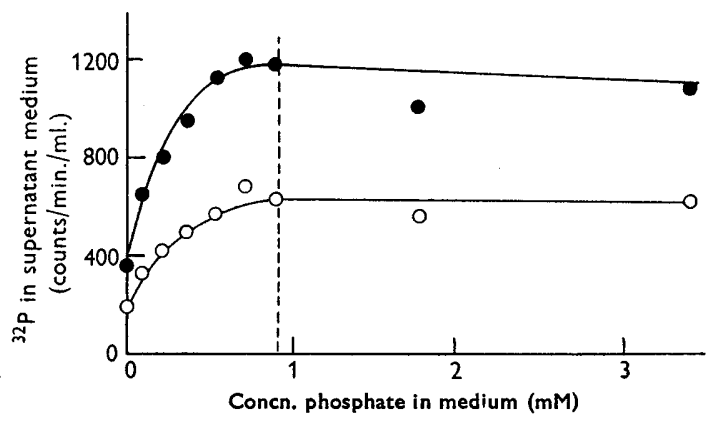

Fig. 2

Fig. 1. Release of ${ }^{32} \mathrm{P}$ from $20 \mathrm{hr}$. chick embryo cell monolayers grown in labelled medium into phosphate-free Earle's saline (P-free ES). The labelled plates were washed twice with $5 \mathrm{ml}$. warm complete ES and twice with P-free ES before adding $5 \mathrm{ml}$. warm P-free ES. To one series of plates $(\bullet-\bullet$ and $\triangle-\triangle)$ sufficient phosphate at $\mathrm{pH} 7$ was added in $0.1 \mathrm{ml}$. of water after $4 \mathrm{hr}$. to restore the $\mathbf{P}$ to its strength in Earle's saline; half of this series $(\Delta-\Delta)$ had the phosphate-containing ES removed $1 \mathrm{hr}$. later, was washed twice with warm P-free ES and $5 \mathrm{ml}$. warm P-free ES substituted. The arrows represent the points of addition and removal respectively of external phosphate.

Fig. 2. Effects of varying the concentration of external phosphate on the rate of ${ }^{\mathbf{S} P} \mathbf{P}$ release from labelled $20 \mathrm{hr}$. chick embryo cell monolayers. The monolayers were washed three times with P-free ES, and $5 \mathrm{ml}$. of warm P-free ES containing varying amounts of added phosphate at $\mathrm{pH} 7$ were added. Samples were removed from the supernatants for ${ }^{32} \mathrm{P}$ assay after $70(\mathrm{O}-\mathrm{O})$ and $135 \mathrm{~min}$. $(\bullet-\bullet)$. The broken line represents the concentration of phosphate in ES. 
at $0^{\circ}$ (Table $3 a$, Cooper, 1957 $b$ ) liberated much inorganic phosphate within $2 \mathrm{~min}$. in sucrose-soluble form. In one experiment a $0.02 \mathrm{ml}$. sample of the sucrose-soluble fraction of frozen-thawed radioactive cells was placed on a filter-paper strip soaked in $\mathbf{0 . 0 5} \mathrm{M}$-sodium citrate buffer $(\mathrm{pH} \mathrm{6.0)}$ in parallel with a $0.01 \mathrm{ml} .0 \cdot 1 \mathrm{M}-\mathrm{Na}_{2} \mathrm{HPO}_{4}$ sample. Without drying the paper, the ends were placed in electrode compartments containing the buffer, the centre portion being immersed in $\mathrm{CCl}_{4}$, while a current of $5 \mathrm{~mA}$. was passed at $800 \mathrm{~V}$ for $1.5 \mathrm{hr}$. The strip was then dried and sprayed with the reagent of Bandurski \& Axelrod (1951) and irradiated with ultraviolet light to develop the blue-green colour characteristic of inorganic phosphate. The orthophosphates produced blue-green spots $22 \mathrm{~cm}$. from the origin which coincided with a peak containing $85 \%$ of the radioactivity of the preparation and $90-100 \%$ of the acid-soluble inorganic ${ }^{32} \mathrm{P}$; under these conditions the mobility of the fastest monophosphate, uridylic acid, would be $60 \%$ of the orthophosphate. There was no 'streaking' of the radioactivity which would indicate decomposition on the paper.

This procedure therefore separated a large proportion of the cellular ${ }^{32} \mathbf{P}$ as a fraction with the same mobility as inorganic orthophosphate. The mildness of the extraction and separation methods used strongly suggests that it is in this form in the intact cell, and the quantitative identity of the orthophosphate with the 'acid-soluble inorganic phosphate' fraction, where other ${ }^{32} \mathbf{P}$ fractions are much smaller, suggests that these fractions are in fact identical. It therefore seems likely, although not proven, that the external phosphate is in reciprocal exchange with an internal pool of free phosphate ions.

\section{Effect of virus infection on the rate of ${ }^{32} \mathrm{P}$ exchange}

Previous results (Cooper, $1957 b$ ) showed that, unlike bacteriophage (Puck $\&$ Lee, 1954) vesicular stomatitis virus infection had no effect on rate of ${ }^{32} \mathbf{P}$ release, if the commencement of release corresponded to the initiation of infection, so that the effective period examined was the first half of the latent period. Fig. 3 shows the first hr. in more detail, and also that when the replacement of radioactive by non-radioactive medium was delayed so that the most rapid release of ${ }^{32} \mathrm{P}$ extended over successively later periods, the lack of viral effect on rate of ${ }^{32} \mathrm{P}$ release could be demonstrated up to the time that exponential virus release was almost complete; a systematic difference in ${ }^{32} \mathbf{P}$ release rate of $10 \%$ should be detectable.

\section{The characteristics of the exchange}

Assuming for Micrococcus pyogenes (Staphylococcus aureus) that the cell-wall transport of phosphate was of the exchange-diffusion type, and that the internal and external pools of inorganic phosphate were homogeneous, Mitchell (1953) derived the theoretical relationship $\ln \left[\frac{1-R_{0}}{1-R_{t}}\right]=k t$ for the process of equilibration during gain or loss experiments. $R_{0}$ and $\boldsymbol{R}_{t}$ were the 'relative specific activities' of either $I$, the internal phosphate (i.e. cellular acid-soluble inorganic 
phosphate) for 'gain' experiments, or $E$, the external phosphate for 'loss' experiments at the beginning of the experiments $(t=0)$ and time $=t$, respectively.

$$
\boldsymbol{R}_{t}=\frac{{ }^{32} \mathbf{P}_{t} \times K}{\mathbf{P}},
$$

where ${ }^{32} \mathrm{P}_{t}=$ total ${ }^{32} \mathrm{P}$ content of $E$ or $I$ at time $=t$ and $\mathbf{P}=$ total phosphate of $E$ or $I$ (constant throughout the experiment). $K$ is defined by the relationship (equation $\mathbf{A}$ ) which exists at complete equilibration:

$$
\frac{{ }^{32} \mathbf{P}_{\infty} \times K}{\mathbf{P}}=R_{\infty} \text {. }
$$

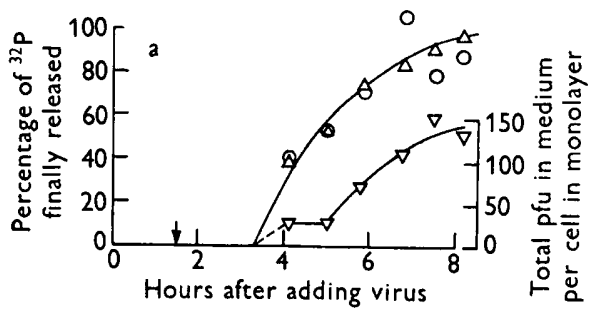

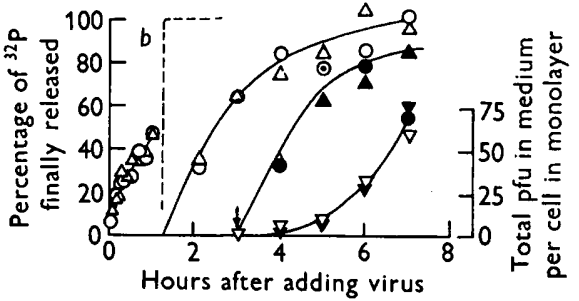

Fig. 3

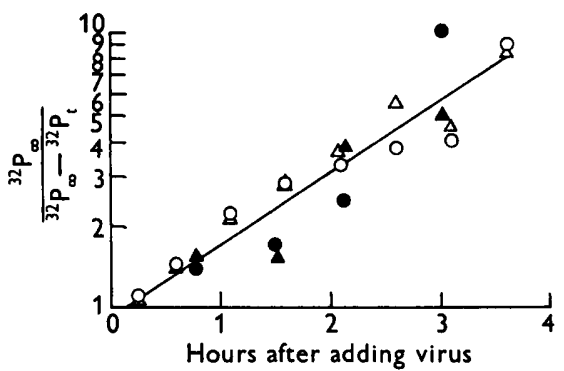

Fig. 4

Fig. 3. Effect of one-step vesicular stomatitis virus infection on the rate of ${ }^{32} \mathrm{P}$ exchange from labelled $20 \mathrm{hr}$. chick embryo cell monolayers. Different portions of the virus release curves are covered by the most rapid periods of ${ }^{32} \mathrm{P}$ release. The labelled medium was removed, virus diluted in $0.5 \mathrm{ml}$. of the labelled medium was added so as to give average multiplicities of adsorption (M) of $6(a)$ and $2(b)$; after $30 \mathrm{~min} .4 .5 \mathrm{ml}$. of the labelled medium was replaced. At various times indicated by the commencement of the release curves after the addition of virus $(1.2$ and $3.0 \mathrm{hr}$., for $\mathrm{M}=2$, and $3.3 \mathrm{hr}$. for $M=6$ ) the medium was removed, the monolayers washed rapidly twice with warm $\mathrm{ES}$ $+4 \%$ ox serum (ES/Ox) and $5 \mathrm{ml}$. non-radioactive ES/Ox added. In one experiment $(0-1 \mathrm{hr} .,(b))$ virus was added to the washed monolayers in $5 \mathrm{ml}$. ES/Ox at the same concentration $\left(10^{8} / \mathrm{ml}\right.$.) as the other curves of $(b)$, so that the multiplicity of adsorption within $30 \mathrm{~min}$. should be about the same (c. 2), and samples were removed at close intervals to examine in detail the period of adsorption (0-1 hr.). The broken vertical line represents the rate of ${ }^{32} \mathrm{P}$ release from ruptured cells. $(O$ and $\bullet)=$ control, and $(\Delta$ and $\Delta)=$ virus-treated monolayers; $(\nabla$ and $\nabla)=$ virus release curves. The arrows indicate the end of the latent period (release of 1 pfu/cell) calculated from logarithmic plots.

Fig. 4. Relationship between $t$ and inorganic orthophosphate ${ }^{32} \mathrm{P}$ in external environment for 'loss' experiments, or in internal environment for 'gain' experiments, after equilibration was complete $\left({ }^{32} \mathrm{P}_{\infty}\right)$, and at time $=t\left({ }^{32} \mathrm{P}_{t}\right)$, for the exchange of phosphate across the chick cell osmotic barrier at $\mathrm{pH} 7$ and $37^{\circ}$. Circles $=$ control and triangles $=$ virus-infected monolayers; open points $={ }^{32} \mathrm{P}$ moving into the cells (gain), filled-in points $={ }^{32} \mathrm{P}$ moving out of the cells (loss). The data is that of figs. 2 and 3 (Cooper, 1957b); the latent period ended at $3 \cdot 7 \mathrm{hr}$. Commencement of equilibration coincided with addition of virus for the loss experiment, but was $0.15 \mathrm{hr}$. after virus for the gain experiment. 
$R_{\infty}$ is defined as $=1$, and ${ }^{32} \mathrm{P}_{\infty}$ as =amount of ${ }^{32} \mathrm{P}$ present in $E$ or $I$ in loss or gain experiments when equilibration was complete. Thus the 'relative specific activities' indicate the completeness of equilibration. Mitchell's equation depended on the demonstration that there was negligible net change of $\mathbf{P}$ during the period of exchange, as was verified experimentally.

The data of Cooper $(\mathbf{1 9 5 7} b)$ indicate that synthesis of organic phosphate in the chick-cell culture system was slow compared with the exchange, and that there was little net change in $\mathbf{P}$ during gain or loss experiments. Using the same arguments and definitions, Mitchell's equation can be adapted to the data available from either the loss or gain experiments with chick embryo cells as follows:

At $t=0, R_{0}=0$, therefore

$$
\ln \left[\frac{1-R_{0}}{1-R_{t}}\right]=\ln \left[\frac{1}{1-{ }^{32} P_{t} K / \mathbf{P}}\right]=\ln \left[\frac{\mathrm{P} / K}{\mathbf{P} / K-{ }^{32} \mathbf{P}_{t}}\right]=k t .
$$

Substituting ${ }^{32} \mathrm{P}_{\infty} / \boldsymbol{R}_{\infty}$ for $\mathrm{P} / K$ (from equation $\mathrm{A}$ ):

$$
\ln \left[\frac{{ }^{32} \mathbf{P}_{\infty}}{{ }^{32} \mathbf{P}_{\infty}-{ }^{32} \mathbf{P}_{t}}\right]=k t \text {. }
$$

Equation (B)

A plot of $\log _{10}\left[\frac{{ }^{32} \mathrm{P}_{\infty}}{{ }^{32} \mathrm{P}_{\infty}-{ }^{32} \mathrm{P}_{t}}\right]$ against time for both the gain and loss experiments presented in figs. 2 and 3 of Cooper (1957 b) (Fig. 4), and also for the gain experiments in Fig. 3 above, showed an approximately linear relationship, suggesting a similar mechanism in chick cells to that operating in Micrococcus pyogenes. No regular difference was noticeable between infected and control points.

\section{DISCUSSION}

It is felt that no mechanisms other than a phosphate-restrictive cell wall can explain the existence of an apparent phosphate-impermeable volume nearly coincident with that of the cell volume, as the specific volume of the cell constituents (as measured by the phosphate-impermeable volume after rupture) is less than $10 \%$ of the cell volume. The very rapid breakdown of this restriction on cell-rupture, together with the close correlation between radioactivity and inorganic orthophosphate after very mild separation, indicates that either the phosphate linkages with any enzymically formed intracellular matrix are unusually labile or that the cell holds its reservoir of orthophosphate in the form of free ions retained by a restrictive cell wall.

It is interesting to discuss the nature of the restriction to phosphate, that is, of the mechanism by which phosphate is allowed to pass the cell wall. It has been pointed out elsewhere (Cooper, 1957 $b$ ) that the 'reversible' acid-soluble inorganic phosphate behaves as a pool which exchanges with the inorganic phosphate of the medium in a largely reciprocal fashion; with a total cell volume of $1180 \mu^{3}$ and $2 \cdot 5 \times 10^{-7} \mu \mathrm{g}$. $\mathrm{P} /$ cell its concentration is at least $6 \cdot 8 \mathrm{~mm}$ or 7 times that of the medium. It has been possible to set up two hypothetical models to explain the way in which this phosphate is concentrated and 
retained. One was that the cell wall is impermeable to phosphate in the physical sense, retaining as in a bag free phosphate ions whose entry requires a specific transport mechanism, and the other that phosphate diffuses physically into the cell at least as rapidly as the exchange process and is then either immobilized in a phosphate-accepting framework by a chemical process, probably enzymic, or retained by Donnan-type equilibria. These two hypotheses were compared above with 'exchange-diffusion' and 'exchange-adsorption' as defined by Mitchell (1953) for Micrococcus pyogenes (Staphylococcus aureus). The fact that the cell appears impermeable to phosphate after only 3 min. of contact with phosphate merely means that any inward physical diffusion is too slow to be measureable within this time. An exponential process $50 \%$ complete in $\mathbf{7 0} \mathrm{min}$. would be only $3 \%$ complete in $3 \mathrm{~min}$. If one can therefore demonstrate, under conditions where any enzymic step is negligible, that the rate of diffusion into or out of the cell at $37^{\circ}$ is slower than the exchange rate at $37^{\circ}$, exchange adsorption as defined above is excluded. It is shown above that liberation of phosphate from the cell is negligible at $0^{\circ}$, and it is mentioned in an appendix that physical diffusion inwards may not predominate at $37^{\circ}$, although more data is required to be certain of this point. These points would therefore favour exchange diffusion.

It is shown above that the kinetics of the exchange are very similar to those of Micrococcus pyogenes (Staphylococcus aureus), which can be justified theoretically from consideration of the exchange-diffusion mechanism. It is more than likely that the proportion of the 'exchange' apparently due to physical diffusion is a result of some damage to the cell surfaces during handling. It is interesting that the rate of exchange of phosphate is maximal at about physiological concentrations (Fig. 2); the $50 \%$ equilibration time is 70-90 min. Addition of external phosphate to P-free ES at once initiated the exchange (Fig. 1), and subsequent removal allowed only the slow release again.

Having shown that the relatively slow exchange of phosphate with the medium (compared with the much more rapid release or entry after cell rupture) is due to a restriction at the cell surface. Whatever the nature of this restriction, the lack of effect of VS virus infection on this exchange makes it possible to say that both penetration and release of this virus can result in only a very limited lysis of the cell wall. At all events, release is certainly not accompanied by a 'burst' in the sense in which the term is applied to the release of bacteriophage. This conclusion has frequently been drawn from other types of observations with other viruses (Dulbecco, 1955). Similarly, the fact that ${ }^{32} \mathrm{P}$ release is not retarded by the virus shows that any enzymicallydependent transport is not grossly damaged by passage of the virus.

I am very grateful to my colleagues at the California Institute for stimulating discussions, in particular Dr R. Dulbecco and Dr G. W. Beadle, and to the Gosney Fund Board of Trustees, the American Cancer Society Inc., and the American Cancer Society, California Division, for financial support as a Research Fellow. I am indebted to the Wright-Fleming Institute of Microbiology, St Mary's Hospital, London, for leave-of-absence. 


\section{REFERENCES}

Bandurski, R. S. \& Axelrod, B. (1951). The chromatographic identification of some biologically important phosphate esters. J. biol. Chem. 193, 405.

Cooper, P. D. $(1957 a)$. Some characteristics of vesicular stomatitis virus growth curves in tissue culture. J. gen. Microbiol. 17, 327.

Cooper, P. D. (1957b). Paths of phosphate transfer in normal chick embryo cells and in cells infected with vesicular stomatitis virus. J. gen. Microbiol. 17, 335.

Dulbecco, R. (1955). Interactions of viruses and animal cells. A study of facts and interpretations. Physiol. Rev. 35, 301.

Dulbecco, R. \& Vogt, M. (1954). One-step growth curve of western equine encephalomyelitis virus on chicken embryo cells grown in vitro and analysis of virus yields from single cells. J. exp. Med. 99, 183.

GreenberG, D. M. (1952). The acid-soluble phosphates in animal metabolism. Phosphorus metabolism, vol. II, p. 3. A symposium. Ed. W. D. McElroy and B. Glass. Baltimore: Johns Hopkins Press.

Kamen, M. D. \& Spiegelman, S. (1948). Studies on the phosphate metabolism of some unicellular organisms. Cold Spr. Harb. Symp. quant. Biol. 13, 151.

Mrtchell, P. (1953). Transport of phosphate across the surface of $M$. pyogenes: nature of the cell' inorganic phosphate'. J. gen. Microbiol. 9, 273.

Mrtchell, P. \& Moyle, J. (1953). Paths of phosphate transfer in M. pyogenes: phosphate turnover in nucleic acids and other fractions. J. gen. Microbiol. 9, 257.

Mitcheld, P. \& Moyle, J. (1956). Osmotic function and structure in bacteria. In Bacterial Anatomy. Symp. Soc. gen. Microbiol. 6, 150.

Puck, T. T. \& LeE, H. H. (1954). Mechanism of cell wall penetration by viruses. I. An increase in host cell permeability induced by bacteriophage infection. J. exp. Med. 99, 481.

SACKs, J. (1948). Mechanism of phosphate transfer across cell membranes. Cold Spr. Harb. Symp. quant. Biol. 13, 180.

\section{APPENDIX}

An approximation to the kinetics of the entry of phosphate into the cell at $0^{\circ}$ can be obtained from the 'phosphate-impermeable volume' data after $3 \mathrm{hr}$. at $0^{\circ}$ (Table 1 ). If the same principles apply to a process of reversible diffusion at $0^{\circ}$ as to the exchange at $37^{\circ}$, the relationship

$$
\ln \left[\frac{{ }^{32} \mathbf{P}_{\infty}}{{ }^{32} \mathbf{P}_{\infty}-{ }^{32} \mathbf{P}_{t}}\right]=k_{0} t
$$

will also hold. Presumably the 'phosphate-impermeable volume' does not actually shrink, but rather the data indicates a progressive diffusion of phosphate from the external space (volume $=V_{e} \mathrm{ml}$.) to the internal $\left(V_{i} \mathrm{ml}\right.$. , $=$ phosphate impermeable volume at $t=0$ ). It is further assumed that the cell's internal volume remains constant during the experiment. Then ${ }^{32} P_{\infty}$, the ${ }^{32} \mathrm{P}$ content of the internal space at complete equilibration, $=\frac{T . V_{i}}{\bar{V}_{e}+V_{i}}$, where $T=$ total ${ }^{32} \mathrm{P}$ content of the system, since then the internal and external concentrations should be approximately equal (the internal total inorganic phosphate, at c. $7 \mathrm{~mm}$, is of the same order as the external phosphate (10 mM) in this experiment). 
In Table 1, the 'phosphate-impermeable volume' $=c . \frac{1}{2} V_{i}$ after $3 \mathrm{hr}$. The external concentration of ${ }^{32} \mathrm{P}$ is then $=\frac{T}{V_{e}+\frac{1}{2} V_{i}}$ and the amount of ${ }^{32} \mathrm{P}$ in the external space $=\frac{T \cdot V_{e}}{V_{e}+\frac{1}{2} V_{i}}$.

Therefore the internal ${ }^{32} \mathrm{P}_{t}=T-\left[\frac{T \cdot V_{e}}{V_{e}+\frac{1}{2} V_{i}}\right]=\frac{T \cdot V_{i}}{2 V_{e}+V_{i}}$.

Therefore

Therefore

$$
\frac{{ }^{32} \mathrm{P}_{\infty}}{{ }^{32} \mathrm{P}_{\infty}-{ }^{32} \mathrm{P}_{t}}=\frac{1}{1-\left[\frac{V_{e}+V_{i}}{2 V_{e}+V_{i}}\right]}=2+\frac{V_{i}}{V_{e}} .
$$

$$
\ln \left[2+\frac{V_{i}}{V_{e}}\right]=k t \text { (from equation B). }
$$

(Equation C)

where $t^{\prime}=$ time at which the phosphate impermeable volume $=\frac{1}{2} V_{i}$.

In the exchange experiments of Fig. $4, V_{i} / V_{e}$ is very small and $t^{\prime}=1 \cdot 2 \mathrm{hr}$.; the value of $\frac{{ }^{32} \mathrm{P}_{\infty}}{{ }^{32} \mathrm{P}_{\infty}-{ }^{32} \mathrm{P}_{t}}=2$ gives a $50 \%$ equilibration time of $70-90 \mathrm{~min}$., which in this case therefore coincides with the time at which the phosphateimpermeable volume appears to be $=\frac{1}{2} V_{i}$. From equation $(\mathrm{B}), k_{37}=0.58 \mathrm{hr} .^{-1}$. $V_{i} / V_{e}$ is larger in the experiment of Table $1(c .0 \cdot 2)$, giving, on the basis of the single point at $3 \mathrm{hr}$., where the phosphate-impermeable volume happens to be $\frac{1}{2} V_{i}$, a value for $k_{0}$ for the entry of phosphate at $0^{\circ}$ of $0 \cdot 26 \mathrm{hr} .{ }^{-1}$, or approximately one-half that of the $k$ value for entry at $37^{\circ}$ (Equation $\mathrm{C}$ ). Thus the effect of temperature appears considerably greater than one would expect from a purely physical mode of entry, suggesting that as for 'loss' the physical process is not predominant at $37^{\circ}$. 